\title{
Dry semi-continuous anaerobic digestion of food waste in the mesophilic and thermophilic modes: New aspects of sustainable management and energy recovery in South Korea
}

\author{
Dinh Duc Nguyen ${ }^{\mathrm{a}, \mathrm{b}}$, Soon Woong Chang ${ }^{\mathrm{b}, \Uparrow}$, Jae Hun Cha ${ }^{\mathrm{a}}$, Seong Yeob Jeong ${ }^{\mathrm{a}}$, Yong Soo Yoon ${ }^{\mathrm{c}}$, Sin Jin Lee ${ }^{\mathrm{b}}$, \\ Minh Chi Tran ${ }^{\mathrm{d}}$, Huu Hao Ngo ${ }^{\mathrm{e}, \Uparrow}$ \\ ${ }^{a}$ Department for Management of Science and Technology Development \& Faculty of Environment and Labour Safety, Ton Duc Thang \\ University, Ho Chi Minh City, Viet Nam \\ ${ }^{\mathrm{b}}$ Department of Environmental Energy \& Engineering, Kyonggi University, 442-760, Republic of Korea \\ ${ }^{\mathrm{c}}$ Department of Chemical Engineering, Dankook University, 448-701, Republic of Korea \\ ${ }^{\mathrm{d}}$ Institute for Tropicalization and Environment (ITE), Ho Chi Minh City, Viet Nam \\ e Centre for Technology in Water and Wastewater, School of Civil and Environmental Engineering, University of Technology, Sydney \\ (UTS), Australia
}

^Corresponding authors.

E-mail addresses: nguyendinhduc@tdt.edu.vn (D.D. Nguyen), swchang@kyonggi.ac.kr (S.W. Chang), huuhao.ngo@uts.edu.au (H.H. Ngo).

Keywords: Mesophilic and thermophilic digester; Dry anaerobic digestion; Food waste in Korea; Biogas production; Volatile fatty acids

\begin{abstract}
In this study, parallel, bench-scale, mesophilic and thermophilic, dry, semi-continuous anaerobic digestion (DScAD) of Korea food waste (FW, containing $22 \%$ total solids (TS) and $20 \%$ volatile solids (VS)) was investigated thoroughly under varying operational conditions, including hydraulic retention times (HRTs) and organic loading rates (OLRs). The aim was to evaluate the start-up, stability, overall removal efficiency, and inhibitory effects of toxic compounds on process performance over a long-term operation lasting 100 days. The results from both digesters indicate that the simultaneous reduction of VS and the production of gas improved as the HRT decreased or the OLR increased. The highest average rates of VS reduction (79.67\%) and biogas production $\left(162.14 \mathrm{~m}^{3}\right.$ biogas/ton of $\left.\mathrm{FW}, 61.89 \% \mathrm{CH}_{4}\right)$, at an OLR of $8.62 \pm 0.34 \mathrm{~kg} \mathrm{VS} / \mathrm{m}^{3}$ day (25 days of HRT), were achieved under thermophilic DScAD. In addition, the average rates of reduction of VS and the production of biogas in thermophilic DScAD were higher by $6.88 \%$ and $16.4 \%$, respectively, than were those in mesophilic DScAD. The inhibitory effects of ammonia, $\mathrm{H}_{2} \mathrm{~S}$, and volatile fatty acids (VFAs) on methane production was not clear from either of the digesters, although, apparently, their concentrations did fluctuate. This fluctuation could be attributed to the self-adaptation of the microbial well. However, digestion that was more stable and faster was observed under thermophilic conditions compared with that under mesophilic conditions. Based on our results, the optimum operational parameters to improve FW treatment and achieve higher energy yields could be determined, expanding the application of DScAD in treating organic wastes.
\end{abstract}

\section{Introduction}

Harnessing energy from waste benefits society and the environment and simultaneously conserves energy and creates a sustainable energy source. The greenhouse effect has led to adverse climate changes across the Earth and has become a cause of grave concern globally [1]. In order to reduce global greenhouse gas emissions significantly, multiple solutions need to be implemented concurrently, particularly in the major industrialized countries. Priority has to be given to ensuring that significant transition occurs from using fossil fuels to alternative energy sources that are cheap, renewable, and nonpolluting [2]. Renewable energy sources, such as tidal, geothermal, hydroelectric, and wind power could be employed in some countries. However, such sources are not expected to become the principal sources of energy in the near future [3].

Large quantities of food waste (FW) are produced worldwide every day. In South Korea, particularly, the average generation of FW reached 49,753 ton/day, accounting for $26.75 \%$ of the municipal solid waste over a period of 11 years, from 2003 to 2014 [4]. Generally, FW is the main waste stream of organic solid waste in urban areas [5]. Food waste could be considered a resource, as it represents a significant source of alternative energy [6,7].

Over the last several decades, ocean dumping, landfills, incineration, recycling as animal feed, and composting have been commonly employed for FW treatment. However, since the banning 
of ocean dumping, the space available for landfills has come under pressure and the associated government regulations have become stricter [8]. In addition, the land waste application is being managed increasingly to protect human health and the environment from the potentially harmful constituents typically found in FW, such as pathogens, heavy metals, and toxic organic chemicals [911]. Moreover, the incineration of $\mathrm{FW}$ could generate dioxins [10] and is energy intensive [12,13], whereas the recycling of FW as animal feed and compost is less in demand owing to the poor quality of the products [14]. However, dry anaerobic digestion (AD) is a feasible biological process, in which organic matter is degraded by the combined action of a highly diverse microbial community (consisting of several groups of microorganisms), and, subsequently, converted into biogas [15]. This technique has been developed and applied widely because of its economic advantages in comparison with the other treatment processes [16]. In recent years, dry AD from FW has increasingly caught the attention of scientists, mainly because of the advantages of the technique in comparison with wet AD. These include energy recovery, the capacity to operate at high OLRs [17], high rates of biogas production [18], applicability to a wide range of organic wastes, potential by-products [19], and cost-effective technology $[18,20]$. However, wet $\mathrm{AD}$ also has several advantages, such as smaller digester volumes, smaller footprint, lower leachate production, cheaper construction, and lower energy consumption [21].

In contrast with the advantages of the technique, dry AD has several limitations that have to be clarified, such as limited rates of methane production, longer retention and start-up time, large quantities of sludge seeding, the effects of accumulated VFA and toxic compounds, as well as sensitivity to small changes in the operating parameters (temperature, $\mathrm{pH}$, nutrient, and others) $[16,17,22,23]$. However, extremely large quantities of FW with high organic matter are being produced in Korea daily. This presents an opportunity to utilize $\mathrm{FW}$ as a renewable energy source in the most effective way at an early stage. Concurrently, employing this technique responds to the waste-to-energy policy and the goal of the South Korean government to increase the portion of new and renewable energy by 2050 [24]. However, as the application of dry AD of FW in Korea is still in its infancy, there is a lack of research data on developing and applying this technique to match local conditions for potential energy recovery and sustainable FW management [25]. For these reasons, the modifications required for the sustainable operation of a dry AD process were employed in the FW treatment method followed in this study.

In this study, the mesophilic and thermophilic dry semicontinuous anaerobic digestion (DScAD) methods were evaluated and compared, with respect to their practical applicability for treating food waste (FW) at various high OLRs. In addition, this study comprehensively compared the performance of these two digesters in relation to the reduction of solids, production of biogas, percentage of methane in the biogas, and the effects of total volatile fatty acid (TVFA) and individual VFA on the methanogenic communities.

\section{Materials and methods}

\subsection{Food waste and inoculation}

Source-separated FWs were collected from restaurants located at Kyonggi University, crushed into small pieces to a diameter of less than $2 \mathrm{~mm}$, and used as feedstock for the anaerobic digestion experiments. After crushing, small quantities of the FW, barely enough for daily feeding into the digesters, were placed in zipper bags and stored in a refrigerator at 4 oC. The inoculum sludge was collected from the FW digestion plant in Pusan city, South Korea. The characteristics of FW and inoculum sludge are shown in Table 1.

\subsection{Digester setup, description, and operational conditions}

A schematic diagram of the semi-continuous anaerobic digester system used in this study is shown in Fig. 1.

Two continuously stirred type digesters (digester A and digester B) were employed for mesophilic and thermophilic dry anaerobic digestion. The operating temperatures were $38 \pm 0.1$ oC for the mesophilic process and $55 \pm 0.1$ oC for the thermophilic process. Both digesters were equipped with a hot-water jacket system, which was thermostatically controlled by the re-circulating pump of the water heater. Each digester had an independent electric control system and agitator for constant churning at $30 \mathrm{rpm}$ to ensure that the substrate and the inoculum were blended completely. All apparatus used in the systems were controlled automatically. The total volume of each digester was $20 \mathrm{~L}$ whereas the working volume was $10 \mathrm{~L}$. Ten liters of seed sludge was added to the reactor and purged with $\mathrm{N}_{2}$ gas for 10 min to create anaerobic conditions. The digesters were fed raw FW and withdrawal digestate every day at the same amounts of $100 \mathrm{~g} / \mathrm{day}, 166 \mathrm{~g} /$ day, $333 \mathrm{~g} /$ day, and $400 \mathrm{~g} / \mathrm{L}$, during phase 1 , phase 2 , phase 3 , and phase 4 , respectively, corresponding to OLRs of $2.16 \mathrm{~kg} \mathrm{VS} / \mathrm{m}^{3}$ day (phase 1), $3.58 \mathrm{~kg} \mathrm{VS} / \mathrm{m}^{3}$ day (phase 2), $7.18 \mathrm{~kg} \mathrm{VS} / \mathrm{m}^{3}$ day (phase 3), and $8.62 \mathrm{~kg} \mathrm{VS} / \mathrm{m}^{3}$ day (phase 4). The corresponding hydraulic retention times (HRTs) were approximately 100 days, 60 days, 30 days, and 25 days, respectively, at a fixed solid content of $20 \%$ TS. After seeding the sludge, no FW was injected into nor sludge waste discharged from either digester for eight days. Additionally, both the digesters were operated at the same HRT, OLR, TS, and temperature conditions during phases 1 and 2. During phase 3, the temperature of the digester $\mathrm{B}$ was gradually increased from 38 oC to 55 oC at a rate of 1 oC every two days.

\subsection{Analytical methods}

The samples of influent and effluent digestion sludge and the biogas were collected and analyzed every day during the study period to evaluate the digester performance.

The concentration of total solids (TS), volatile solids (VS), total nitrogen $(\mathrm{TN})$, ammonia nitrogen $\left(\mathrm{NH}_{4}-\mathrm{N}\right)$, total phosphorus (TP), total chemical oxygen demand (TCOD), alkalinity (Alk.), and $\mathrm{pH}$ were measured according to standard methods [26]. The volume of biogas produced in the reactor was measured by using a wet gas meter (W-NK-0.5, Shinagawa Corporation, Japan) and a Tedlar bag for gas sampling. The analysis of the gas composition $\left(\mathrm{CH}_{4}\right.$, $\mathrm{CO}_{2}, \mathrm{NH}_{3}$-gas, and $\mathrm{H}_{2} \mathrm{~S}$ ) was carried out by using a biogas analyzer (GSR-3100, Sensoronic Co., Ltd., South Korea). The amount of volatile fatty acids (VFAs) was determined by using a packed-column gas chromatograph (GC; Agilent 7890A, Agilent Technologies, Inc., USA), equipped with a flame ionization detector and SGE BP21 capillary wax column ( $25 \mathrm{~m}$ length $\times 0.53 \mathrm{~mm}$ ID $\times 0.5 \mathrm{~lm}$ df) (Agilent Technologies, Inc., USA), and with nitrogen as carrier gas. Approximately $2 \mathrm{lL}$ of each sample was injected into the GC. The initial temperature of the GC column was $60 \mathrm{oC}$, which was increased at a rate of $5 \mathrm{oC} / \mathrm{min}$ to $120 \mathrm{oC}$. It was subsequently

Table 1

Characteristics of the food waste and inoculum sludge used in the experiment.

\begin{tabular}{llll}
\hline Parameters & Unit & Food waste & Inoculum \\
\hline $\mathrm{pH}$ & - & 4.91 & 7.62 \\
Total solids (TS) & $\%$ & $23.02 \pm 2.22$ & $20.02 \pm 0.95$ \\
Volatile solids (VS) & $\%$ & $20.55 \pm 0.84$ & $12.59 \pm 0.71$ \\
VS/TS & $\%$ & $91.53 \pm 2.34$ & $69.54 \pm 2.30$ \\
Total chemical oxygen demand (TCOD) & $\mathrm{g} / \mathrm{kg}$ & 220 & 72 \\
Total nitrogen $(\mathrm{TN})$ & $\mathrm{mg} / \mathrm{kg}$ & 3650 & 4200 \\
Ammonia nitrogen $\left(\mathrm{NH}_{4}-\mathrm{N}\right)$ & $\mathrm{mg} / \mathrm{kg}$ & 900 & 1800 \\
& & & \\
\hline
\end{tabular}




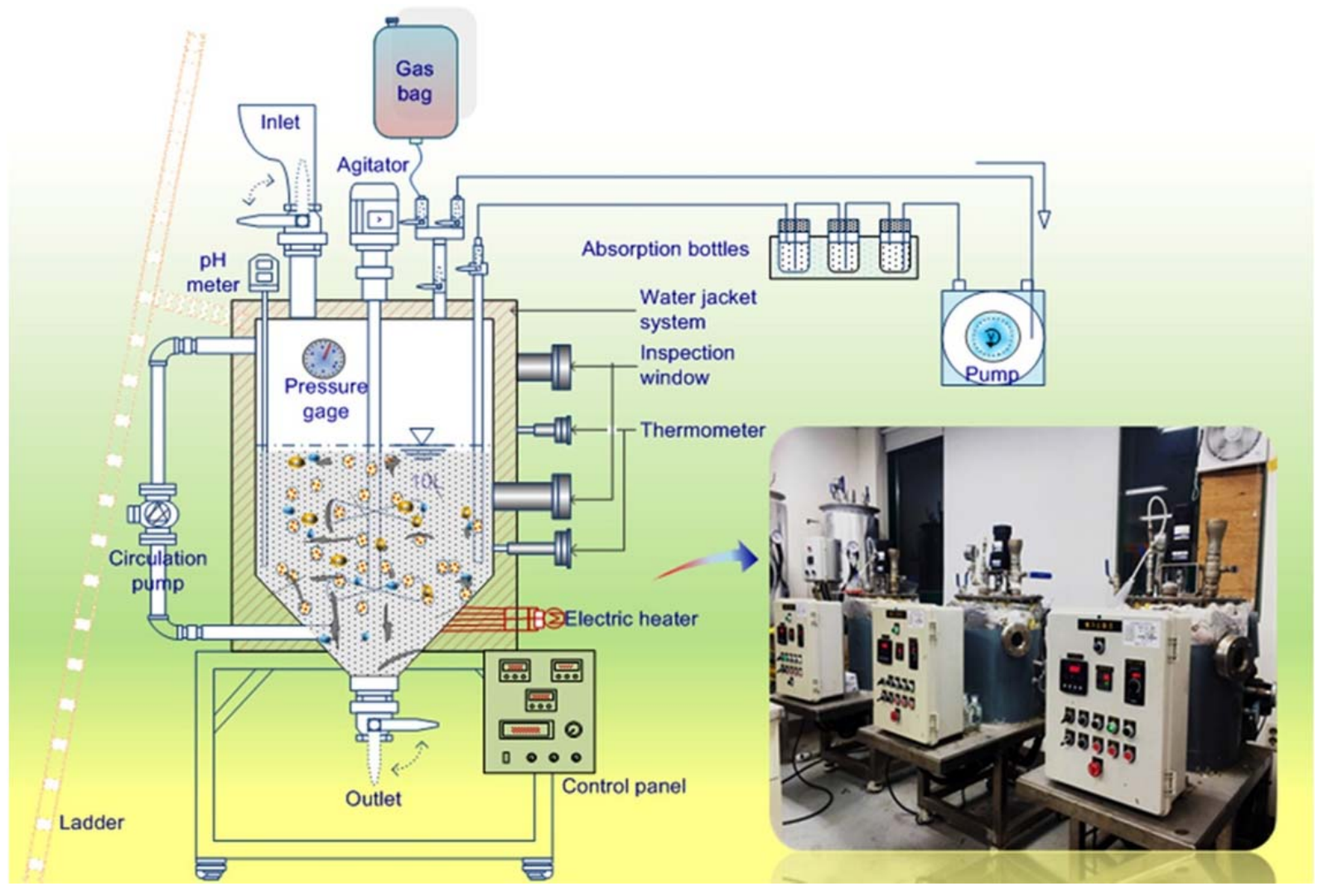

Fig. 1. Schematic diagram of the dry anaerobic digestion system.

increased at a rate of $10 \mathrm{oC} / \mathrm{min}$ to a final temperature of $230 \mathrm{oC}$. The injector temperature was set at 200 oC, while that of the flame ionization detector was set at 230 oC [27].

\section{Results and discussion}

\subsection{Organic matter reduction}

The consumption patterns of OLR and VS during the four operating periods of the dry semi-continuous anaerobic digesters were similar, as shown in Fig. 2. The ability of the system to adapt to the change in retention time was investigated, and the process in both digesters was stabilized. The results obtained (Fig. 2 and Table 2) indicate that during the course of the operation an increase in the biodegradation of the organic matter was observed when the consumption of organic matter increased (Fig. 2a). This occurred under both operating conditions, despite the increase in OLR (decrease in HRT), resulting in higher organic matter removal (Fig. 2b). Subsequently, this contributed to achieving greater efficiency and a favorable volumetric biogas production rate. Depending on the amount of organic load input, this would make it possible to predict the effect of reducing the amount of organic matter in anaerobic digesters.

The values of the operating organic loading rates (OLRo) applied to both DScAD were maintained at $2.16 \pm 0.08,3.58 \pm 0.14$, $7.18 \pm 0.28$, and $8.62 \pm 0.34 \mathrm{~kg} \mathrm{VS} / \mathrm{m}^{3}$ day, respectively, for phase 1 (HRT 100 days), phase 2 (HRT 60 days), phase 3 (HRT 30 days), and phase 4 (HRT 25 days).

As the results depicted in Fig. 2b demonstrate, the removal efficiency in each of the early phases in the digesters tended to be unstable owing to sudden changes in the operating OLRs. Therefore, to overcome this instability, an adaptation period was needed for the microorganisms in the digesters. Particularly in phase 1 and phase 2, a short period of one to two days was needed for the microorganisms to adapt; however, as the OLR increased, the time required for the microorganisms in the digester to adapt also increased, as can be seen in phases 3 and 4 . For example, when the operating OLR reached $7.18 \pm 0.28 \mathrm{~kg} \mathrm{VS} / \mathrm{m}^{3}$ day (phase 3), the time needed for the anaerobic bacteria to adapt in both digesters was approximately five to eight days, which resulted in a VS reduction of 59-64\%. Further, when the operating OLR increased by approximately $20 \%\left(8.62 \pm 0.34 \mathrm{~kg} \mathrm{VS} / \mathrm{m}^{3}\right.$ day, phase 4$)$, the minimum amount of time required to adapt was 26-30 days in order to achieve a VS reduction of $81.19 \pm 2.68 \%$ under thermophilic conditions, and approximately 30-34 days to achieve a VS reduction of $72.99 \pm 3.86 \%$ under mesophilic conditions.

In addition, the results showed that for the dry anaerobic digesters, the period of adaptation for anaerobic microbial activity after increase in the OLR was not only faster in thermophilic conditions but was also much more efficient in removing VS than under mesophilic conditions. These results show that higher consumption of specific organic matter and higher removal of VS were achieved within a relatively short acclimation period compared with those reported for municipal solid waste in other studies [28-32]. This suggests that the thermophilic DScAD carried out in this study was effective.

The evidence from the results mentioned above indicates that the highest VS removal efficiency was achieved during phase 4 (HRT 25 days, OLRo $=8.62 \pm 0.34 \mathrm{~kg} \mathrm{VS} / \mathrm{m}^{3}$ day) in both the ADs, whereas the thermophilic mode of operation was more stable, faster, and achieved higher VS reduction and higher OLR than the mesophilic mode. It is believed that thermophilic operating conditions create an environment that is more favorable to the growth and intense activity of the anaerobic microbial population. 


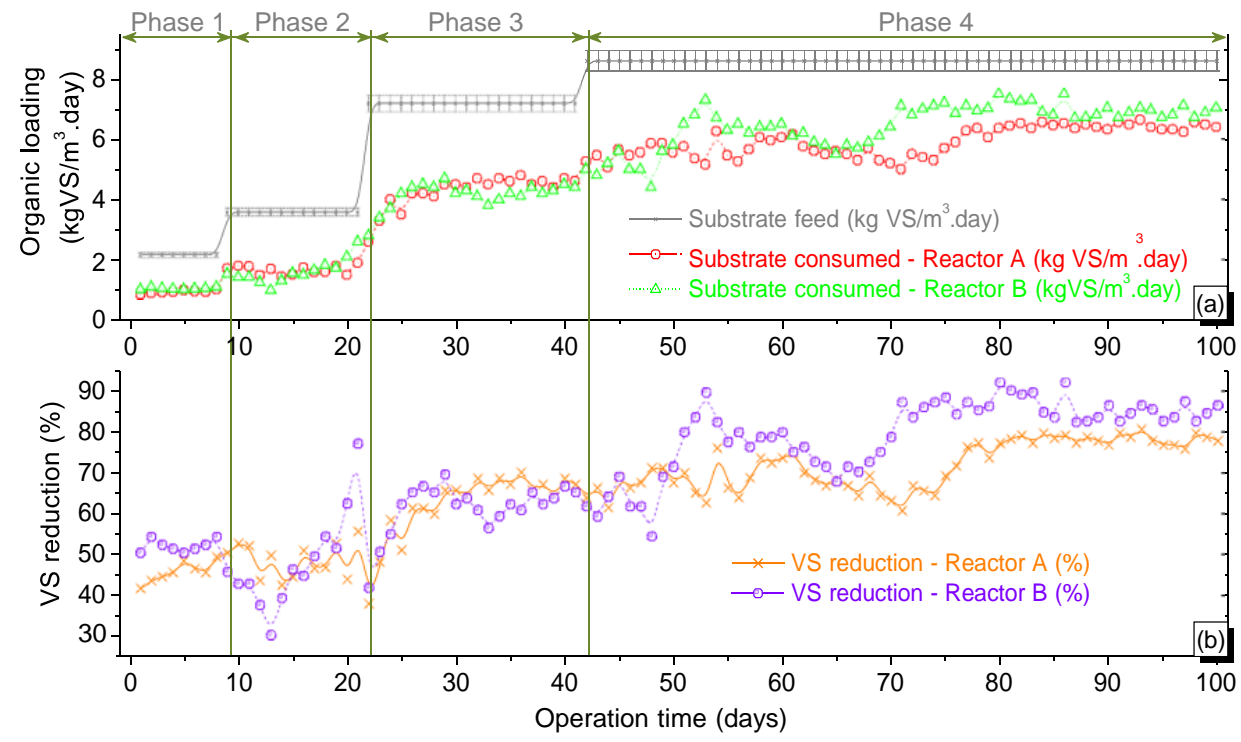

Fig. 2. Variation of OLRo, specific organic matter consumed (OLRc), and VS reduction in both anaerobic digesters during operation.

Table 2

Summary of the overall OLRs and VS reduction in each of the phases during operation.

\begin{tabular}{|c|c|c|c|c|}
\hline Phase & $\begin{array}{l}\text { HRT } \\
\text { (days) }\end{array}$ & $\begin{array}{l}\text { OLRo } \\
\text { kg VS/m³ day }\end{array}$ & $\begin{array}{l}\text { Digester A } \\
\text { VS removal } \\
(\%)\end{array}$ & $\begin{array}{l}\text { Digester B } \\
\text { VS removal } \\
(\%)\end{array}$ \\
\hline 1 & 100 & $2.16 \pm 0.08$ & $43.63 \pm 2.4$ & $48.84 \pm 1.47$ \\
\hline 2 & 60 & $3.58 \pm 0.14$ & $46.39 \pm 4.03$ & $44.91 \pm 11.3$ \\
\hline 3 & 30 & $7.18 \pm 0.28$ & $59.47 \pm 7.72$ & $57.52 \pm 6.05$ \\
\hline Steady state & 30 & $7.18 \pm 0.28$ & $63.94 \pm 1.81$ & $58.62 \pm 2.82$ \\
\hline 4 & 25 & $8.62 \pm 0.34$ & $68.63 \pm 5.61$ & $74.97 \pm 8.52$ \\
\hline Steady state & 25 & $8.62 \pm 0.34$ & $74.54 \pm 1.31$ & $79.67 \pm 1.72$ \\
\hline
\end{tabular}

Avg. \pm Stdev.: Average \pm Standard deviation.

Steady state: A period during a phase where the biological process is expected to have reached a state of stable performance.

\subsection{Biogas production}

The adaptation of the seeding inoculum to the feed stock and the operational conditions is an important issue in anaerobic digestion [30]. For dry anaerobic digestion, particularly, which involves the treatment of high concentrations of solids, the concentration of biomass in the reactor has to be high as well. However, the sludge from wet digesters, with a concentration of less than $5 \%$ VS, has often been used as a seeding source, which, however, requires a longer start-up period to develop a highly concentrated microbial community and achieve a stable performance [31,33,34]. In this study, dry digester FW with a VS concentration of $12.59 \pm 0.71 \%$ was used as the main seeding source in an effort to reduce the start-up period. The success of this strategy is evident from the biogas and biomethane $\left(\mathrm{CH}_{4}\right)$ being generated in both digesters from the first day of the experiment (Figs. 3 and 4).

Four phases, corresponding to the four different values of solid retention times, were carried out to evaluate the effect of this parameter on the process performance of gas production at a fixed solid-content level of approximately $20 \%$ TS. The $\mathrm{pH}$ in AD is a crucial factor that can have a pronounced effect on microbial activities, thereby affecting the digester performance and biogas production. However, during each phase of this study, the variation in $\mathrm{pH}$ was found to be within a favorable range of 6.6-8.1. This was achieved despite the obvious increase in the OLR during each run period in both digesters, changes in the VFA levels, and the average concentration of alkalinity in the digester A being slightly higher than that in the digester $\mathrm{B}$.
The variations in biogas generation and the specific gas yield in both digesters during the operation are shown in Figs. 3 and 4. As seen from the results presented in Figs. 3 and 4 and Table 3, the gas yield consistently increased in both digesters, despite the increase in OLRs or the decrease in HRTs. This means that the gas yield in the digesters increased as the OLRs increased, achieving an average rate of biogas production during treatment in phase 1 , phase 2, phase 3 , and phase 4 , equal to $0.18 \pm 0.07,0.3 \pm 0.09,0.44 \pm 0.06$, and $0.53 \pm 0.11 \mathrm{~m}^{3}$ biogas $/ \mathrm{kg} \mathrm{VS}_{\text {fed }}$, respectively, in digester $\mathrm{A}$. An average rate of biogas production of $0.17 \pm 0.06,0.23 \pm 0.16$, $0.44 \pm 0.07$, and $0.58 \pm 0.15 \mathrm{~m}^{3}$ biogas $/ \mathrm{kg} \mathrm{VS}_{\text {fed }}$, respectively, was achieved in digester $B$. In addition, the average biomethane content in the biogas produced was $41.31 \pm 2.8 \%, 60.59 \pm 5.29 \%$, $56.9 \pm 6.17 \%$, and $60.79 \pm 5.6 \%$, respectively, in digester $\mathrm{A}$, and $42.25 \pm 2.6 \%, 55.15 \pm 10.16 \%, 53.63 \pm 3.81 \%$, and $56.56 \pm 5.32 \%$, respectively, in digester $B$.

The results obtained for phase 4 indicate that the average specific gas production, the rate of biogas production, and the methane content in steady-state conditions (from the 87th day of investigation onwards) was $0.65 \pm 0.03 \mathrm{~m}^{3} / \mathrm{kg} \mathrm{VS}_{\text {fed }}, 139.29 \pm 6.08 \mathrm{~m}^{3}$ biogas/ton FW, and $66.82 \pm 1.93 \%$, respectively, for mesophilic DScAD (Fig. 3). It was $0.75 \pm 0.02 \mathrm{~m}^{3} / \mathrm{kg} \mathrm{VS}_{\text {fed }}, 162.14 \pm 4.58 \mathrm{~m}^{3}$ biogas/ ton FW, and $61.89 \pm 2.74 \%$, respectively, for thermophilic DScAD (Fig. 4). Despite being generated simultaneously and under the same conditions, the yields of biogas $\left(162.14 \pm 4.58 \mathrm{~m}^{3} /\right.$ ton FW) and methane $\left(\mathrm{CH}_{4}, 100.32 \pm 4.59 \mathrm{~m}^{3} /\right.$ ton $\left.\mathrm{FW}\right)$ obtained from thermophilic DScAD were $16.4 \%$ and $7.87 \%$ higher than were those from mesophilic DScAD. However, the methane concentration was the 


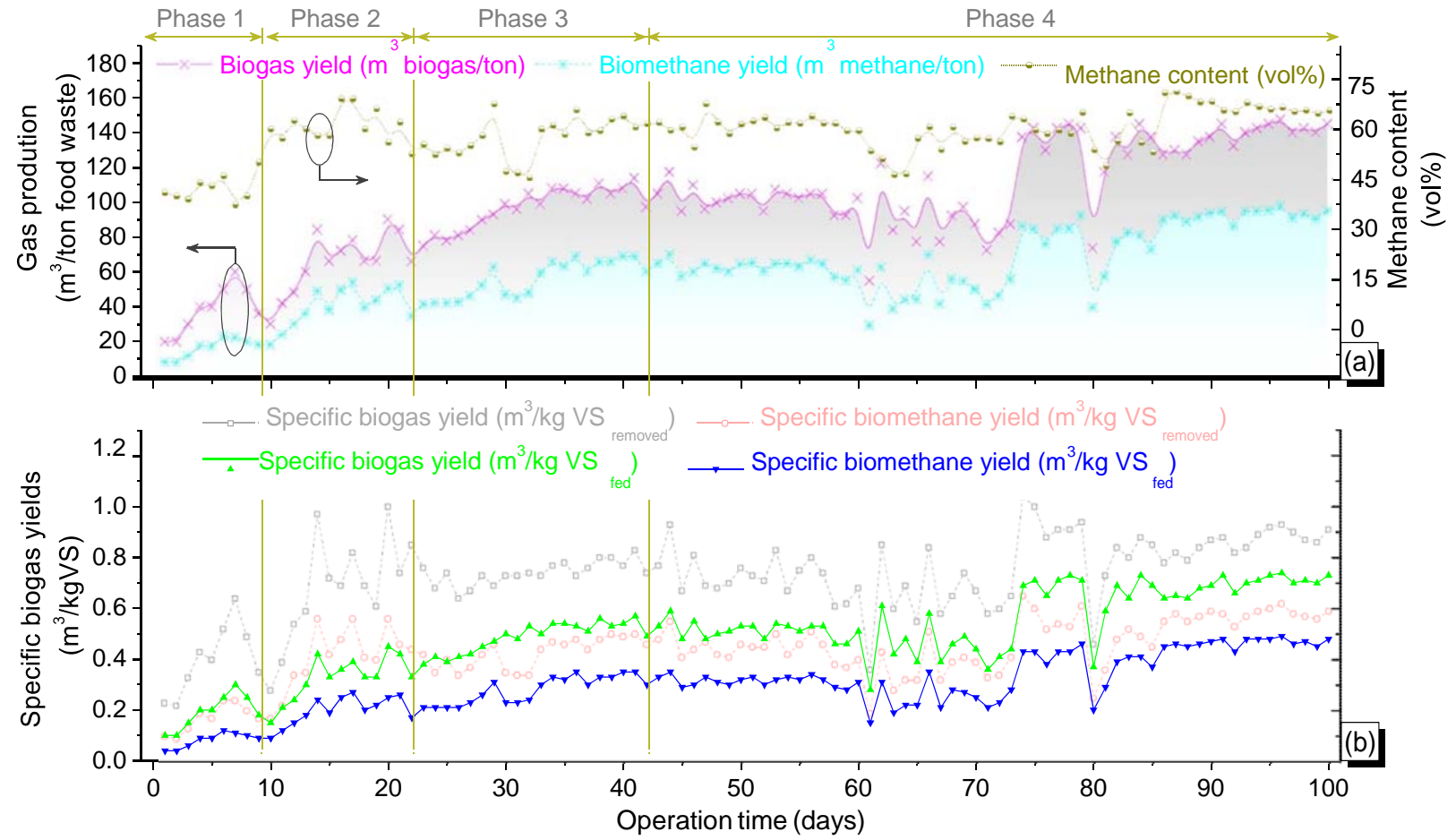

Fig. 3. Variation of biogas and biomethane production in digester A during the operation.

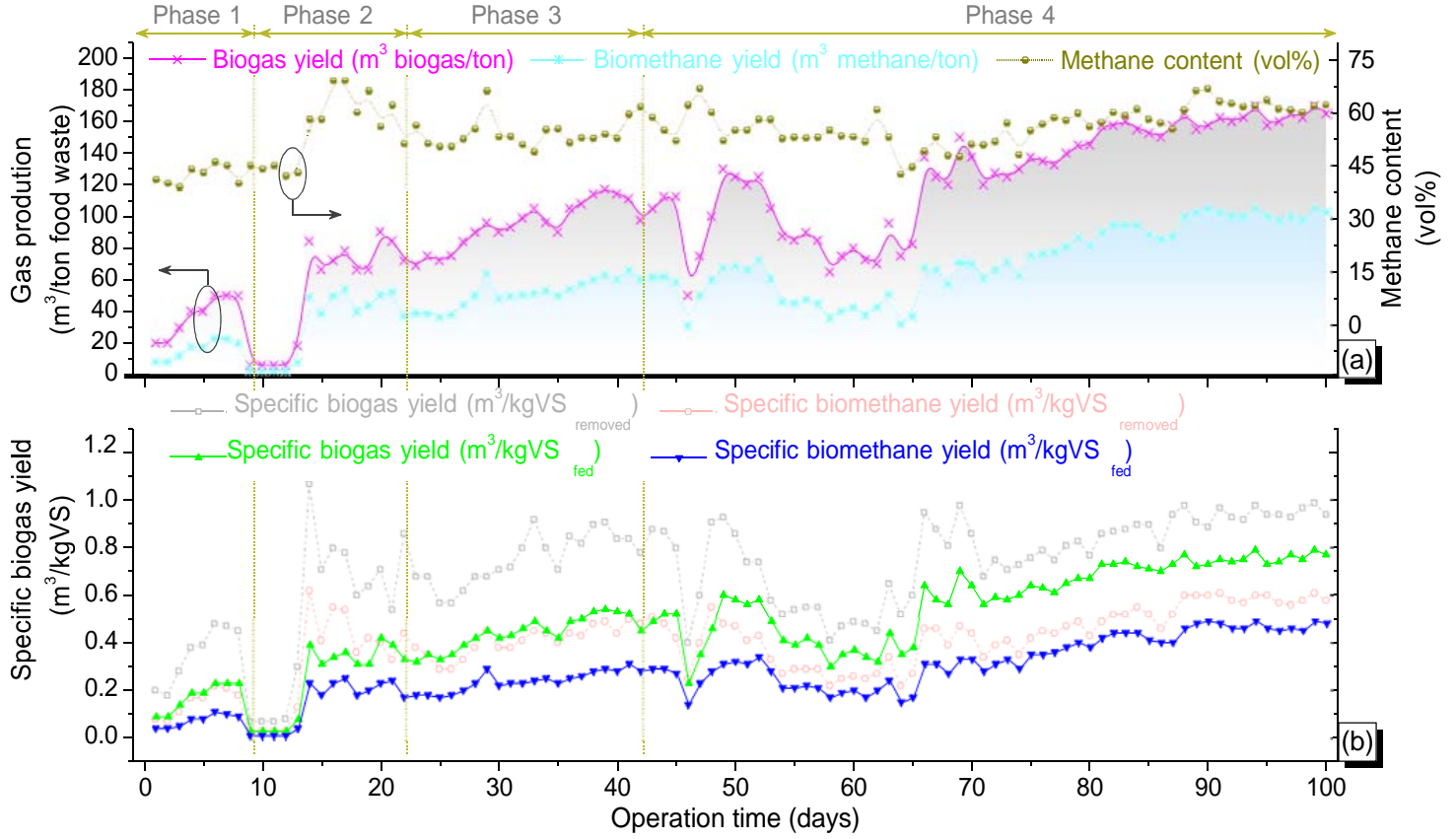

Fig. 4. Variation of biogas and biomethane production in digester B during the operation.

inverse of the biogas production, which could be explained by the rapid adaptation and presence of multiple active bacterial populations at high concentrations in the thermophilic DScAD. This accelerated the metabolism of organic compounds and, consequently, the biogas production, thereby expanding the potential for their application in treating organic waste. Other researchers [35,36] have also observed that the thermophilic digester achieved higher COD removal and biogas yield in comparison with the mesophilic digester during the anaerobic digestion of a combination of wastewater from an olive mill and waste from an abattoir.

Compared with various other studies [28,37,38], the technique used in this study not only required a shorter start-up time but also resulted in higher biogas production. Additionally, although the same anaerobic digester was used in each phase, the acclimation period required to achieve steady-state biogas production was 1.66-1.72 times longer than was the acclimation period required 
Table 3

Summary of the performance of mesophilic and thermophilic DScADs at different OLRs.

\begin{tabular}{|c|c|c|c|c|c|c|}
\hline \multirow[t]{2}{*}{ Phase } & \multirow{2}{*}{$\begin{array}{l}\text { OLRo } \\
\left(\mathrm{kg} \mathrm{VS} / \mathrm{m}^{3} \mathrm{~d}\right)\end{array}$} & \multirow{2}{*}{$\begin{array}{l}\text { Biogas yield } \\
\left(\mathrm{m}^{3} / \mathrm{kg} \mathrm{VS} \mathrm{Ved}_{\mathrm{fe}}\right.\end{array}$} & \multirow[b]{2}{*}{$\left(\mathrm{m}^{3} /\right.$ ton $)$} & \multirow{2}{*}{$\begin{array}{l}\mathrm{CH}_{4} \text { yield } \\
\left(\mathrm{m}^{3} / \mathrm{kg} \mathrm{VS} \mathrm{Sed}\right)\end{array}$} & \multirow[b]{2}{*}{$\left(\mathrm{m}^{3} /\right.$ ton $)$} & \multirow[b]{2}{*}{ (\% content) } \\
\hline & & & & & & \\
\hline \multicolumn{7}{|l|}{ Digester A } \\
\hline 1 & $2.16 \pm 0.08$ & $0.18 \pm 0.07$ & $38.75 \pm 14.58$ & $0.07 \pm 0.03$ & $16.03 \pm 6.03$ & $41.31 \pm 2.81$ \\
\hline 2 & $3.58 \pm 0.14$ & $0.3 \pm 0.09$ & $63.49 \pm 19.31$ & $0.18 \pm 0.06$ & $38.78 \pm 12.79$ & $60.59 \pm 5.29$ \\
\hline 3 & $7.18 \pm 0.28$ & $0.44 \pm 0.06$ & $95.5 \pm 13.73$ & $0.25 \pm 0.05$ & $54.64 \pm 11.45$ & $56.9 \pm 6.17$ \\
\hline Steady state & & $0.49 \pm 0.02$ & $105.65 \pm 5.17$ & $0.29 \pm 0.04$ & $61.89 \pm 8.37$ & $58.46 \pm 6.48$ \\
\hline 4 & $8.62 \pm 0.34$ & $0.53 \pm 0.11$ & $114.31 \pm 24$ & $0.32 \pm 0.08$ & $70.11 \pm 18.28$ & $60.79 \pm 5.6$ \\
\hline Steady state & & $0.65 \pm 0.03$ & $139.29 \pm 6.08$ & $0.43 \pm 0.01$ & $93 \pm 3.05$ & $66.82 \pm 1.93$ \\
\hline \multicolumn{7}{|l|}{ Digester B } \\
\hline 1 & $2.16 \pm 0.08$ & $0.17 \pm 0.06$ & $37.5 \pm 12.82$ & $0.07 \pm 0.03$ & $16.03 \pm 6.03$ & $42.25 \pm 2.6$ \\
\hline 2 & $3.58 \pm 0.14$ & $0.23 \pm 0.16$ & $50.05 \pm 35.16$ & $0.14 \pm 0.1$ & $30.46 \pm 22.53$ & $55.15 \pm 10.16$ \\
\hline 3 & $7.18 \pm 0.28$ & $0.44 \pm 0.07$ & $93.84 \pm 15.49$ & $0.23 \pm 0.04$ & $50.41 \pm 9.44$ & $53.63 \pm 3.81$ \\
\hline Steady state & & $0.49 \pm 0.04$ & $104.83 \pm 9.15$ & $0.26 \pm 0.03$ & $55.87 \pm 5.74$ & $53.3 \pm 2.76$ \\
\hline 4 & $8.62 \pm 0.34$ & $0.58 \pm 0.15$ & $125.94 \pm 32.98$ & $0.33 \pm 0.1$ & $71.92 \pm 22.4$ & $56.56 \pm 5.32$ \\
\hline Steady state & & $0.75 \pm 0.02$ & $162.14 \pm 4.58$ & $0.47 \pm 0.02$ & $100.32 \pm 4.59$ & $61.89 \pm 2.74$ \\
\hline
\end{tabular}

Avg. \pm Stdev.: Average \pm Standard deviation.

The average and standard deviation were calculated based on the total samples of the phase, including the results of the samples during the unstable period.

to achieve stable metabolism of VS (Figs. 2-4). This could be explained by the time required after each increase of OLR to enable the population of organisms to become acclimated to the additional biodegradable organic resource, to grow, and to synthesize new cells.

These results reaffirm the higher yield of methane gas that has been achieved in the thermophilic digester (Table 3), indicating the success of the study to determine a potential source for biogas energy. In addition, these results can serve to predict the performance of the mesophilic and thermophilic digesters under different OLRs relevant to biogas production and the reduction of organic matter. Accordingly, this research has demonstrated that DScADs can serve the dual purpose of FW reduction and improvement of biogas production from treated FW at a high OLR. This finding demonstrates the potential for the reduction of the environmental footprint of the whole system and the high potential for energy recovery.

\subsection{Accumulation of VFAs}

Volatile fatty acids are the intermediary products of the anaerobic digestion process and are mainly produced by acidogenic and acetogenic bacterial populations [39,40]. The accumulation of VFAs in anaerobic digesters could have various causes, such as excessive organic loading, changes in temperature, lower ratio of inoculum, and the accumulation of toxic compounds [41-43]. The accumulation of large amounts of (TVFAs) in mesophilic and thermophilic anaerobic digesters can result in an imbalance in the fermentation process, which, ultimately, could lead to the failure of the process [44-47].

In this study, two parallel anaerobic digesters were operated under the same HRT, OLRo, and TS conditions in each phase. Other short-chain organic acids, for example valeric, caproic, and enanthic acids, are termed "etc. VFAs" in this study. Individual VFAs (acetic acid, propionic acid, butyric acid, and etc. VFAs) and TVFA in the mixtures in both anaerobic digesters are shown in Fig. 5. Overall, these increased proportionally with the increasing operating OLRo, with acetic acid and propionic acid being predominant, corresponding to a percentage concentration in the 53.9-77.1\% and $15-42.3 \%$ range, respectively, in the digester $A$, and the $36.6-69.9 \%$ and $19.7-55.6 \%$ range, respectively, in the digester $\mathrm{B}$.

The results obtained (Fig. 5, Table 4) indicate that the total concentration of VFAs in both the digesters during phases 1 and 2 was less than $0.25 \mathrm{~g} / \mathrm{L}$, but in phase 3 (OLRo of $7.18 \pm 0.28 \mathrm{~kg} \mathrm{VS} /$ $\mathrm{m}^{3}$ day), the operating temperature of the digester $\mathrm{B}$ rose gradually from $38 \mathrm{oC}$ to $55 \mathrm{oC}$, at a rate of $1 \mathrm{oC}$ for two days, to ensure a thermophilic mode of operation, for which the DScAD had been designed. The concentration of TVFA increased during phases 3 and 4 , to reach average values of $1.85 \pm 0.65 \mathrm{mg} / \mathrm{L}$ (with $67.6 \pm 9 \%$ acetic acid, $30.3 \pm 8.6 \%$ propionic acid, and $1.6 \%$ butyric acid) and $4.49 \pm 0.90 \mathrm{~g} / \mathrm{L}$ (with $70.5 \pm 7.1 \%$ acetic acid, $19 \pm 4.2 \%$ propionic acid, and $3.3 \pm 0.3 \%$ butyric acid), respectively, in the digester $\mathrm{A}$. In digester $\mathrm{B}$, the values were $1.77 \pm 0.69 \mathrm{~g} / \mathrm{L}$ (with $64.1 \pm 4.6 \%$ acetic acid, $26.8 \pm 6 \%$ propionic acid, and $6.7 \pm 2.2 \%$ butyric acid) and $5.84 \pm 1.02 \mathrm{~g} / \mathrm{L}$ (with $50.5 \pm 6.2 \%$ acetic acid, $30.7 \pm 4.8 \%$ propionic acid, $11 \pm 3.3 \%$ butyric acid), respectively. The $\mathrm{NH}_{4}-\mathrm{N}$ concentrations in the samples gradually increased during the entire period of operation, from $1.38 \mathrm{~g} / \mathrm{L}$ (phase 1 ) to $3.4 \mathrm{~g} / \mathrm{L}$ (phase 4 ) in the dry anaerobic digester $\mathrm{A}$, and from $1.8 \mathrm{~g} / \mathrm{L}$ (phase 1) to $3.7 \mathrm{~g} / \mathrm{L}$ (phase 4) in the dry anaerobic digester B. Consequently, a higher concentration of $\mathrm{NH}_{4}-\mathrm{N}$ was found in the digester $\mathrm{B}$ compared with the digester $\mathrm{A}$.

Interestingly, in both digesters, the peaks in TVFA concentration were observed on day 84 , during phase 4 . However, the TVFA levels were $25.2 \%$ higher in the digester B (thermophilic condition) than in the digester A (mesophilic condition). Once the maximum values of $5.67 \mathrm{~g}$ TVFA/L in the mesophilic mode (54.0\% acetic acid, $29.1 \%$ propionic acid, and $4.1 \%$ butyric acid) and $7.10 \mathrm{~g}$ TVFA/L in the thermophilic mode (43.0\% acetic acid, $32.5 \%$ propionic acid, and $10.6 \%$ butyric acid) had been reached, the TVFA returned to a stable level of $5.45 \pm 0.03 \mathrm{~g}$ TVFA/L in the mesophilic mode (73 $\pm 2.8 \%$ acetic acid, $15.4 \pm 0.3 \%$ propionic acid, and $3.9 \pm 2 \%$ butyric acid) and $6.29 \pm 0.50 \mathrm{~g}$ TVFA $/ \mathrm{L}$ in the thermophilic mode $(55.9 \pm 3.9 \%$ acetic acid, $24.4 \pm 0.2 \%$ propionic acid, and $15.1 \pm 0.4 \%$ butyric acid). However, no decrease in $\mathrm{pH}$ was observed because of the accumulation of VFAs, while the alkalinity was maintained in the $10-11 \mathrm{~g} / \mathrm{L}$ range as $\mathrm{CaCO}_{3}$. Consequently, there was no reduction in the generation of methane because of the accumulation of VFAs.

Furthermore, the observed experimental results showed that the ratio of propionic acid/acetic acid varied in a range of $0.21-$ 1.77 in the digester $\mathrm{A}$ and $0.28-1.52$ in the digester $\mathrm{B}$, whereas the concentrations of acetic acid negligibly increased during the course of the study. No significant differences emerged between the experiments in two digesters. However, the rate of increase was faster and higher in the concentration of acetic acid compared with the other VFAs, such as propionic acid and butyric acid.

It could be concluded from the results that the average accumulation of TVFAs was $15.44 \%$ higher in the thermophilic DScAD than in the mesophilic DScAD. The microorganism populations in both 

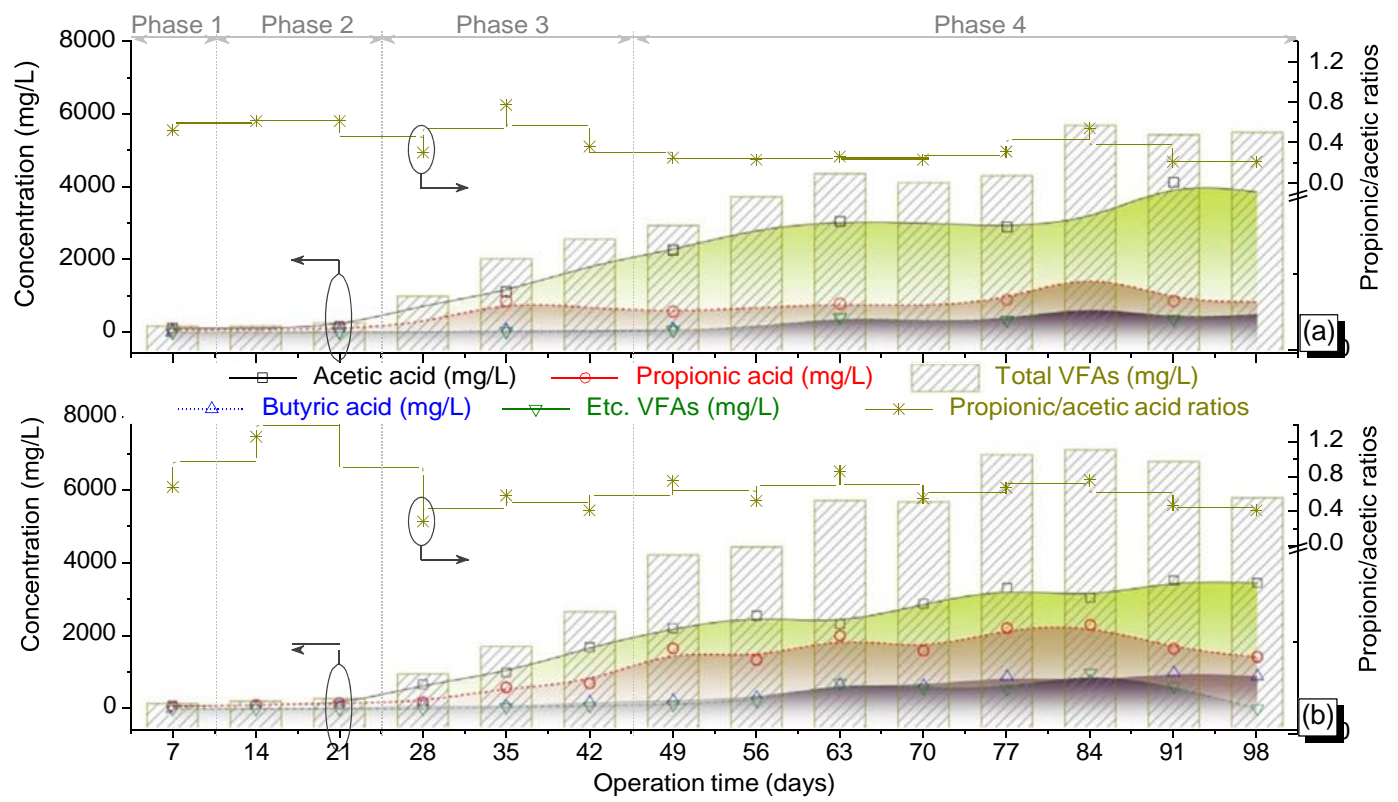

Fig. 5. Concentration of individual and total VFAs in the (a) anaerobic digester A and (b) anaerobic digester B during operation at different OLRs.

Table 4

Variation of volatile fatty acids in anaerobic digesters.

\begin{tabular}{|c|c|c|c|c|c|c|c|c|}
\hline \multirow[t]{2}{*}{ Phase } & \multirow{2}{*}{$\begin{array}{l}\text { Acetic acid } \\
\mathrm{mg} / \mathrm{L}\end{array}$} & \multirow[b]{2}{*}{$\%$} & \multirow{2}{*}{$\begin{array}{l}\text { Propionic acid } \\
\mathrm{mg} / \mathrm{L}\end{array}$} & \multirow[b]{2}{*}{$\%$} & \multirow{2}{*}{$\begin{array}{l}\text { Butyric acid } \\
\mathrm{mg} / \mathrm{L}\end{array}$} & \multirow[b]{2}{*}{$\%$} & \multirow{2}{*}{$\begin{array}{l}\text { Etc. VFAs } \\
\mathrm{mg} / \mathrm{L}\end{array}$} & \multirow{2}{*}{$\begin{array}{l}\text { Total VFAs } \\
\mathrm{mg} / \mathrm{L}\end{array}$} \\
\hline & & & & & & & & \\
\hline \multicolumn{9}{|c|}{ In dry semi-continuous anaerobic digester A } \\
\hline Phase 1 & 105 & 65.60 & 55 & 34 & 0 & 0 & 0 & 160 \\
\hline Phase 2 & $122 \pm 23$ & $59.7 \pm 2.6$ & $74.5 \pm 14.5$ & $36.4 \pm 1.3$ & $10 \pm 10$ & $3.9 \pm 3.9$ & 0 & $206.5 \pm 47.5$ \\
\hline Phase 3 & $1231.3 \pm 456.4$ & $67.6 \pm 9$ & $577.7 \pm 262.2$ & $30.3 \pm 8.6$ & $30.3 \pm 10.8$ & $1.6 \pm 0$ & $9.3 \pm 8.2$ & $1848.7 \pm 649.1$ \\
\hline Phase 4 & $3128.8 \pm 548.2$ & $70.5 \pm 7.1$ & $862.8 \pm 314.9$ & $19 \pm 4.2$ & $152.9 \pm 83.9$ & $3.3 \pm 1.3$ & $348.4 \pm 195.5$ & $4492.8 \pm 901.8$ \\
\hline Steady state & $3975 \pm 133$ & $73 \pm 2.8$ & $836.5 \pm 12.5$ & $15.4 \pm 0.3$ & $212.5 \pm 108.5$ & $3.9 \pm 2$ & $423 \pm 66$ & $5447 \pm 29$ \\
\hline \multicolumn{9}{|c|}{ In dry semi-continuous anaerobic digester B } \\
\hline Phase 1 & 88 & 59.50 & 60 & 40.50 & 0 & 0 & 0 & 148 \\
\hline Phase 2 & $95 \pm 9$ & $38.9 \pm 2.3$ & $133 \pm 25$ & $53.7 \pm 2$ & $18.5 \pm 3.5$ & $7.5 \pm 0.3$ & 0 & $246.5 \pm 37.5$ \\
\hline Phase 3 & $1122 \pm 427.1$ & $64.1 \pm 4.6$ & $491.7 \pm 219.6$ & $26.8 \pm 6$ & $112.3 \pm 50.1$ & $6.7 \pm 2.2$ & $48.7 \pm 30.7$ & $1774.7 \pm 698.1$ \\
\hline Phase 4 & $2917.5 \pm 477.4$ & $50.5 \pm 6.2$ & $1773.6 \pm 336.2$ & $30.7 \pm 4.8$ & $668.5 \pm 260.3$ & $11 \pm 3.3$ & $477.9 \pm 308.4$ & $5837.5 \pm 1025.1$ \\
\hline Steady state & $3493.5 \pm 35.5$ & $55.9 \pm 3.9$ & $1536 \pm 111$ & $24.4 \pm 0.2$ & $946 \pm 49$ & $15.1 \pm 0.4$ & $312.5 \pm 303.5$ & $6288 \pm 499$ \\
\hline
\end{tabular}

digesters were able to adapt to and withstand the changes in the VFA levels. The VFA exerted no apparent influence on the biogas production or performance of each dry anaerobic digestion process during the stable periods of the phases, despite the significant variation in the VFAs in the two digesters.

\section{Conclusions}

The proposed dry anaerobic digesters for FW with high solids content were thoroughly investigated to assess the performance and inhibitory effects of toxic compounds at different OLRs and HRTs. The main findings are:

- The stepwise increase in OLR resulted in a simultaneous increase in the reduction of VS and the production of biogas.

- The thermophilic mode of operation was faster, with higher treatment efficiency, compared with the mesophilic mode relevant to substrate degradation and biogas yield, even at higher loading rates.

- Increasing the OLR from 2.2 to $8.6 \mathrm{~kg} \mathrm{VS} / \mathrm{m}^{3}$ day did not have any clear effect on either the operation of the microbial communities or the performance of the dry anaerobic digester during the stable periods of operation.
- VFA showed no apparent inhibitory effect on the rate of its conversion into biogas in either of the digesters.

- Acetic and propionic acids dominated the TVFAs during all phases of the both dry anaerobic digesters.

- The startup time interval required for the dry mesophilic and thermophilic anaerobic digestion systems to adapt depended on the OLR. However, digestion under the thermophilic conditions was observed to be more stable, faster, and efficient than under the mesophilic conditions.

\section{Acknowledgements}

This project was supported by grants from the Korea Ministry of Environment as a "Global Top Project” (Project No. 2016002200005). The authors are very grateful for the research collaboration between Kyonggi University, South Korea and University of Technology Sydney, Australia.

\section{References}

[1] Lau LC, Lee KT, Mohamed AR. Global warming mitigation and renewable energy policy development from the Kyoto Protocol to the Copenhagen Accord-a comment. Renew Sustain Energy Rev 2012;16:5280-4. 
[2] Saxena RC, Adhikari DK, Goyal HB. Biomass-based energy fuel through biochemical routes: a review. Renew Sustain Energy Rev 2009;13:167-78.

[3] Zidanšek A, Blinc R, Jeglič A, Kabashi S, Bekteshi S, Šlaus I. Climate changes, biofuels and the sustainable future. Int J Hydrogen Energy 2009;34:6980-3.

[4] W.M.R.B. Korea Ministry of Environment. Korea Ministry of Environment; 2016.

[5] Kim S-H, Shin H-S. Effects of base-pretreatment on continuous enriched culture for hydrogen production from food waste. Int J Hydrogen Energy 2008;33:5266-74.

[6] Koch K, Helmreich B, Drewes JE. Co-digestion of food waste in municipal wastewater treatment plants: effect of different mixtures on methane yield and hydrolysis rate constant. Appl Energy 2015;137:250-5.

[7] Caton PA, Carr MA, Kim SS, Beautyman MJ. Energy recovery from waste food by combustion or gasification with the potential for regenerative dehydration: a case study. Energy Convers Manage 2010;51:1157-69.

[8] Browne JD, Murphy JD. Assessment of the resource associated with biomethane from food waste. Appl Energy 2013;104:170-7.

[9] Fytili D, Zabaniotou A. Utilization of sewage sludge in EU application of old and new methods-a review. Renew Sustain Energy Rev 2008;12:116-40.

[10] Chasek PS, Downie DL, Brown J. Global environmental politics. Westview Press; 2013.

[11] Wu L-J, Kobayashi T, Li Y-Y, Xu K-Q. Comparison of single-stage and temperature-phased two-stage anaerobic digestion of oily food waste. Energy Convers Manage 2015;106:1174-82.

[12] Cheng J, Ding L, Lin R, Liu M, Zhou J, Cen K. Physicochemical characterization of typical municipal solid wastes for fermentative hydrogen and methane coproduction. Energy Convers Manage 2016;117:297-304.

[13] Tan ST, Ho WS, Hashim H, Lee CT, Taib MR, Ho CS. Energy, economic and environmental (3E) analysis of waste-to-energy (WTE) strategies for municipal solid waste (MSW) management in Malaysia. Energy Convers Manage 2015;102:111-20.

[14] Kim D-H, Kim S-H, Shin H-S. Hydrogen fermentation of food waste without inoculum addition. Enzyme Microb Technol 2009;45:181-7.

[15] Elsayed M, Andres Y, Blel W, Gad A, Ahmed A. Effect of VS organic loads and buckwheat husk on methane production by anaerobic co-digestion of primary sludge and wheat straw. Energy Convers Manage 2016;117:538-47.

[16] Elsamadony M, Tawfik A, Suzuki M. Surfactant-enhanced biohydrogen production from organic fraction of municipal solid waste (OFMSW) via dry anaerobic digestion. Appl Energy 2015;149:272-82.

[17] Kothari R, Kumar V, Tyagi VV. Assessment of waste treatment and energy recovery from dairy industrial waste by anaerobic digestion. IIOAB, Special Issue Environ Manage Sustain Develop 2011;2:1-6.

[18] ten Brummeler E. Full scale experience with the BIOCEL process. Water Sci Technol 2000;41:299-304.

[19] Kothari R, Pandey AK, Kumar S, Tyagi VV, Tyagi SK. Different aspects of dry anaerobic digestion for bio-energy: an overview. Renew Sustain Energy Rev 2014;39:174-95.

[20] De Bere L. Anaerobic digestion of solid waste: state-of-the-art. Water Sci Technol 2000;41:283-90.

[21] Li Y-F, Shi J, Nelson MC, Chen P-H, Graf J, Li Y, et al. Impact of different ratios of feedstock to liquid anaerobic digestion effluent on the performance and microbiome of solid-state anaerobic digesters digesting corn stover. Bioresour Technol 2016;200:744-52.

[22] Angelidaki I, Ahring BK. Effects of free long-chain fatty acids on thermophilic anaerobic digestion. Appl Microbiol Biotechnol 1992;37:808-12.

[23] Ghasimi DSM, de Kreuk M, Maeng SK, Zandvoort MH, van Lier JB. High-rate thermophilic bio-methanation of the fine sieved fraction from Dutch municipal raw sewage: cost-effective potentials for on-site energy recovery. Appl Energy 2016;165:569-82.

[24] K.M.o. Environment. Waste-to-energy (current policy focus). Republic of Korea; 2014

[25] Kafle GK, Kim SH. Anaerobic treatment of apple waste with swine manure for biogas production: batch and continuous operation. Appl Energy 2013;103:61-72.

[26] A. APHA. WEF, 2005. Standard methods for the examination of water and wastewater 2005; 21: 258-9.
[27] Nguyen DD, Chang SW, Jeong SY, Jeung J, Kim S, Guo W, et al. Dry thermophilic semi-continuous anaerobic digestion of food waste: performance evaluation, modified Gompertz model analysis, and energy balance. Energy Convers Manage 2016;128:203-10.

[28] de la Rubia MA, Perez M, Romero LI, Sales D. Effect of solids retention time (SRT) on pilot scale anaerobic thermophilic sludge digestion. Process Biochem 2006;41:79-86.

[29] Banks CJ, Stringfellow A. A pilot-scale trial comparing mesophilic and thermophilic digestion for the stabilisation of source segregated kitchen waste. Water Sci Technol 2008.

[30] Güelfo LF-, Alvarez-Gallego C, Márquez DS, García LR. Start-up of thermophilic-dry anaerobic digestion of OFMSW using adapted modified SEBAC inoculum. Bioresour Technol 2010;101:9031-9.

[31] Forster-Carneiro T, Pérez M, Romero L, Sales D. Dry-thermophilic anaerobic digestion of organic fraction of the municipal solid waste: focusing on the inoculum sources. Bioresour Technol 2007;98:3195-203.

[32] Ghosh S, Henry M, Sajjad A, Mensinger M, Arora J. Pilot-scale gasification of municipal solid wastes by high-rate and two-phase anaerobic digestion (TPAD). Water Sci Technol 2000;41:101-10.

[33] Fernández J, Perez M, Romero L. Effect of substrate concentration on dry mesophilic anaerobic digestion of organic fraction of municipal solid waste (OFMSW). Bioresour Technol 2008;99:6075-80.

[34] Montero B, García-Morales J, Sales D, Solera R. Analysis of methanogenic activity in a thermophilic-dry anaerobic reactor: use of fluorescent in situ hybridization. Waste Manage 2009;29:1144-51.

[35] Gannoun H, Othman NB, Bouallagui H, Moktar H. Mesophilic and thermophilic anaerobic co-digestion of olive mill wastewaters and abattoir wastewaters in an upflow anaerobic filter. Ind Eng Chem Res 2007;46:6737-43.

[36] Silvestre G, Illa J, Fernández B, Bonmatí A. Thermophilic anaerobic co-digestion of sewage sludge with grease waste: effect of long chain fatty acids in the methane yield and its dewatering properties. Appl Energy 2014;117:87-94.

[37] Bolzonella D, Innocenti L, Pavan P, Traverso P, Cecchi F. Semi-dry thermophilic anaerobic digestion of the organic fraction of municipal solid waste: focusing on the start-up phase. Bioresour Technol 2003;86:123-9.

[38] Cavinato C, Bolzonella D, Pavan P, Fatone F, Cecchi F. Mesophilic and thermophilic anaerobic co-digestion of waste activated sludge and source sorted biowaste in pilot- and full-scale reactors. Renewable Energy 2013;55:260-5.

[39] Franke-Whittle IH, Walter A, Ebner C, Insam H. Investigation into the effect of high concentrations of volatile fatty acids in anaerobic digestion on methanogenic communities. Waste Manage 2014;34:2080-9.

[40] Zhao M-X, Ruan W-Q. Biogas performance from co-digestion of Taihu algae and kitchen wastes. Energy Convers Manage 2013;75:21-4.

[41] Ali Shah F, Mahmood Q, Maroof Shah M, Pervez A, Ahmad Asad S. Microbial ecology of anaerobic digesters: the key players of anaerobiosis. Sci World J 2014;2014:21.

[42] Raposo F, Fernández-Cegrí V, De la Rubia M, Borja R, Béline F, Cavinato C, et al. Biochemical methane potential (BMP) of solid organic substrates: evaluation of anaerobic biodegradability using data from an international interlaboratory study. J Chem Technol Biotechnol 2011;86:1088-98.

[43] Lübken M, Koch K, Gehring T, Horn H, Wichern M. Parameter estimation and long-term process simulation of a biogas reactor operated under trace elements limitation. Appl Energy 2015;142:352-60.

[44] Kovács E, Wirth R, Maróti G, Bagi Z, Nagy K, Minárovits J, et al. Augmented biogas production from protein-rich substrates and associated metagenomic changes. Bioresour Technol 2015;178:254-61.

[45] Siegert I, Banks C. The effect of volatile fatty acid additions on the anaerobic digestion of cellulose and glucose in batch reactors. Process Biochem 2005;40:3412-8.

[46] Browne JD, Allen E, Murphy JD. Assessing the variability in biomethane production from the organic fraction of municipal solid waste in batch and continuous operation. Appl Energy 2014;128:307-14.

[47] Gao S, Huang Y, Yang L, Wang H, Zhao M, Xu Z, et al. Evaluation the anaerobic digestion performance of solid residual kitchen waste by $\mathrm{NaHCO}_{3}$ buffering. Energy Convers Manage 2015;93:166-74. 